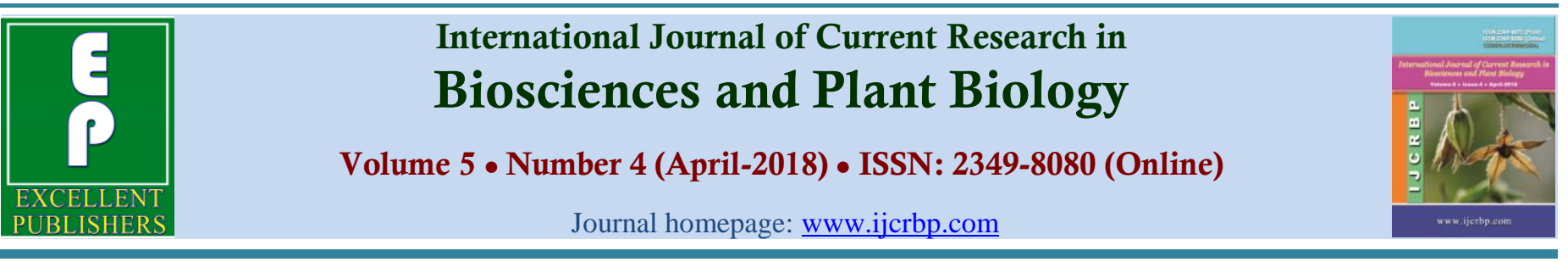

\title{
The Antioxidant Properties of Momordica charantia Extract and its Protective Activities against In Vitro Mercury Intoxication
}

\author{
E. E. Orji*, A. E. Falodun and F. I. Jegede \\ Department of Science Technology and Glass and Ceramics Technology, Federal Polytechnic, \\ Ado-Ekiti, Nigeria \\ *Corresponding author.
}

\begin{tabular}{|c|c|}
\hline Article Info & \multirow{6}{*}{$\begin{array}{l}\text { Momordica charantia is a potent modulator of antioxidant and liver function indices. } \\
\text { This research examines the antioxidant status of the extract and its protective effect on } \\
\text { hepatic and renal system in vitro. The extract scavenges DPPH radicals in a } \\
\text { concentration dependent manner and the reducing power of the extract increases with } \\
\text { concentration. Thus, the homogenate were divided into five groups for the experiment. } \\
\text { The group } 1 \text { is the control that has no intoxicant and extract. The group } 2 \text { contains } \\
\text { homogenate and intoxicant while group } 3 \text { contains homogenate, intoxicant in dose } \\
\text { dependent manner of } 100 \mathrm{ug} / \mathrm{ml}, 500 \mathrm{ug} / \mathrm{ml} \text {, and } 1000 \mathrm{ug} / \mathrm{ml} \text { and likewise group } 4 \text {, but } \\
\text { no intoxicant. In group } 5, \text { the homogenate and intoxicant were treated with quercetin, a } \\
\text { chelator used treatment of } \mathrm{Hg} \text { poisoning. According to result, the extract of Momordica } \\
\text { charantia chelates iron in a concentration dependent manner, thus showing that the } \\
\text { extract has iron chelating activity and acting as primary antioxidant. This study } \\
\text { indicates that Hg administered group significantly reduced the concentration of } \\
\text { kidney-sodium transport and decreased the activities of AST, ALT, GGT, leading to } \\
\text { enzymes inactivation and degradation. Treatments with Momordica charantia extract } \\
\text { help in bringing it back to near normal. }\end{array}$} \\
\hline Date of Acceptance: & \\
\hline 30 March 2018 & \\
\hline $\begin{array}{l}\text { Date of Publication: } \\
06 \text { April } 2018\end{array}$ & \\
\hline Keywords & \\
\hline $\begin{array}{l}\text { Antioxidant } \\
\text { Homogenate } \\
\text { Intoxicant } \\
\text { Mercuric chloride } \\
\text { Momordica charantia }\end{array}$ & \\
\hline
\end{tabular}

\section{Introduction}

Momordica charantia L. commonly known as bitter gourd is an economically important medicinal plant belonging to the family Cucurbitaceae. Two varieties of this plant are cultivated in India. $M$. charantia var. charantia with large fruits which are fusiform in shape are $M$. charantia var. muricata, which are identified by small, round fruit
(Nadkarni, 2007). The immature fruits are eaten as vegetables and are a good source of vitamin $C$, vitamin $\mathrm{A}$ and phosphorus and iron. The bitter flavour of both the varieties is due to the alkaloid momordicine produced in fruits and leaves. Fruits and seeds of bitter gourd possess medicinal properties such as anti-HIV, anti-ulcer, antiinflammatory, anti-leukemic, antimicrobial, anti tumor and last but not the least the important anti 
diabetic property (Ng, et al., 1994; She et al., 1996; Grover and Yadav, 2004; Soundararajan et al., 2012). It contains an array of biologically active plant chemicals including triterpens, proteins, steroids, alkaloids, saponins, flavonoids and acids due to which plant possesses anti-fungal, antibacterial, anti-parasitic, anti-viral, anti-fertility, anti-tumorous, hypoglycaemic and anticarcinogenic properties (Kumar et al., 2010). Fruits are used as traditional medication to cure various diseases like: rheumatism, gout, worms, colic, disease of liver and spleen. It is also found useful in the treatment of cancer and diabetes. It is a potent hypoglycaemic agent due to alkaloids and insulin like peptides and a mixture of steroidal sapogenins known as charantin (Agrawal and Kamal, 2004). The plant is a climbing perennial with elongated fruit that resembles a warty gourd or cucumber. The unripe fruit is white or green in colour and has a bitter taste that becomes more pronounced as the fruit ripens. It is a monoecious climber found throughout the country often under cultivation, up to an altitude of $1500 \mathrm{~m}$. It is a slender climbing annual vine with long-stalked leaves and yellow, solitary male and female flowers borne in the leaf axils.

\section{Materials and methods}

\section{Experimental design}

Homogenates were divided into 5 major groups for the experiment.

Group1: Control

Group 2: $\mathrm{HgCl}_{2}$ administered group (Homogenate + toxicant)

Group 3: $\mathrm{HgCl}_{2}$ administered and extract treated groups (Homogenate + Toxicant + Extract).

a. Homogenate + Toxicant + Extract $(100 \mu \mathrm{g} / \mathrm{ml})$

b. Homogenate + Toxicant + Extract $(500 \mu \mathrm{g} / \mathrm{ml})$

c. Homogenate + Toxicant + Extract $(1000 \mu \mathrm{g} / \mathrm{ml})$

Group 4: extract administered groups (Homogenate + Extract).

a. Homogenate + Extract $(100 \mu \mathrm{g} / \mathrm{ml})$

b. Homogenate + Extract $(500 \mu \mathrm{g} / \mathrm{ml})$

c. Homogenate + Extract $(1000 \mu \mathrm{g} / \mathrm{ml})$

Group 5: $\mathrm{HgCl}_{2}$ administered and quercetin treated group (Homogenate + Toxicant + quercetin)
Test were performed in triplicate, test samples were incubated at $37^{\circ} \mathrm{C}$ for $25 \mathrm{~min}$ and then used for biochemical assays.

Procedure: Male albino rats (Wistar strain) $200 \pm 20 \mathrm{~g}$ were used for the study. Rats were anaesthetized by cervical dislocation and sacrificed loss of consciousness. The livers and kidney were excised, washed in ice cold $1.15 \%$ potassium chloride solution, blotted with filter paper and weighed. They were homogenized in $5 \% \mathrm{w} / \mathrm{v} 0.1 \mathrm{M}$ sodium phosphate buffer ( $\mathrm{pH}$ 7.4) using a Teflon homogenizer. The resulting homogenates were stored at $-20^{\circ} \mathrm{C}$ and then used for biochemical analysis. The plant extract was air dried for 21 days at room temperature before soaking it in water for 72 hours, and freeze dried to obtain the extract used for the analysis.

\section{Assay of reducing power activity}

Extract $(0.5 \mathrm{ml})$ was mixed with $1.25 \mathrm{ml}$ each of phosphate buffer and potassium ferricyanide $\left(\mathrm{C}_{6} \mathrm{~N}_{6} \mathrm{FeK}_{3}\right)$. The mixture was incubated at $50^{\circ} \mathrm{C}$ for $20 \mathrm{~min}$. Trichloroacetic acid $(1.25 \mathrm{ml})$ was then added and the mixture centrifuged at $3000 \mathrm{rpm}$ for $10 \mathrm{~min}$. Thereafter, $1.25 \mathrm{ml}$ of the upper layer of the solution was mixed with $1.25 \mathrm{ml}$ of distilled water and $0.25 \mathrm{ml}$ of $\mathrm{FeCl}_{3}$. The absorbance was read at $700 \mathrm{~nm}$. Higher absorbance of the reaction mixture indicates greater reductive potential.

\section{Assay of DPPH (1, 1-diphenyl-2-picrylhydrazyl) radical scavenging activity}

Exactly $1 \mathrm{ml}$ of $0.3 \mathrm{mM}$ DPPH prepared in methanol was added to $1 \mathrm{ml}$ of extract of various concentrations $(100 \mathrm{~g} / \mathrm{ml}-500 \mu \mathrm{g} / \mathrm{ml})$ and allowed to react at room temperature for $30 \mathrm{~min}$. The reaction mixture was vortexed thoroughly and left in the dark at room temperature for $30 \mathrm{~min}$. The absorbance of the mixture was measured spectrophotometrically at $517 \mathrm{~nm}$ and the percentage scavenging activity was calculated using the formula below.

$\%$ Scavenging activity $=((\mathrm{Ac}-\mathrm{As}) / \mathrm{Ac}) \times 100$ 
Where, Ac is the absorbance of control and As the absorbance of the extract.

\section{Assay for Iron chelating activity}

The iron chelating activity was determined according to the method of Haro-Vicente et al. (2006). Extract $(1 \mathrm{ml})$ was added to $100 \mu \mathrm{l}$ of 1 $\mathrm{mM} \mathrm{FeSO} 4.7 \mathrm{H}_{2} \mathrm{O}$. The reaction mixture was left at room temperature for $2 \mathrm{~min}$. After which 0.5 $\mathrm{ml}$ of $0.5 \mathrm{mM} \mathrm{1,10-phenanthroline} \mathrm{was} \mathrm{added}$ and the mixture was incubated for $10 \mathrm{~min}$ at room temperature. The absorbance was read at $510 \mathrm{~nm}$. The $\mathrm{Fe}^{2+}$ chelating capacity was calculated thus:

$\mathrm{Fe}^{2+}$ chelating activity $(\%)=[(\mathrm{Ac}-\mathrm{As}) / \mathrm{Ac}] \times 100$

\section{Evaluation of aspartate amino transferase (AST) activity}

Diluted sample $(0.1 \mathrm{ml})$ was mixed with $0.5 \mathrm{ml}$ of R1 [phosphate buffer (100 mmol/L, pH 7.4), Laspartate $(100 \mathrm{mmol} / \mathrm{L})$, and $\alpha$-oxoglutarate (2 $\mathrm{mmol} / \mathrm{L})$ ] and the mixture incubated for $30 \mathrm{~min}$ at $37^{\circ} \mathrm{C}$ after which $0.5 \mathrm{ml}$ of $\mathrm{R} 2$ [2, 4dinitrophenylhydrazine $(2 \mathrm{mmol} / \mathrm{L})]$ was added to the reaction mixture and allowed to stand for another $20 \mathrm{~min}$ at $25^{\circ} \mathrm{C}$. Then, $5.0 \mathrm{ml}$ of $\mathrm{NaOH}$ ( $0.4 \mathrm{~mol} / \mathrm{L})$ was added and the absorbance was read against the reagent blank after $5 \mathrm{~min}$ at $546 \mathrm{~nm}$. The activity of AST in homogenate was obtained following the extrapolation of absorbance value on AST standard curve.

\section{Evaluation of alanine amino transferase (ALT) activity}

2, 4-dinitrophenylhydrazine $(2.0 \mathrm{mmol} / \mathrm{l})$ was added and the mixture incubated again at $20^{\circ} \mathrm{C}$ for Reagent1 (0.5 ml) containing Phosphate buffer (100 $\mathrm{mmol} / \mathrm{l}, \mathrm{pH} 7.4)$, L-alanine $(200 \mathrm{mmol} / \mathrm{l})$ and $\alpha$ oxoglutarate $(2.0 \mathrm{~mol} / \mathrm{l})$ was added to a test tube already containing $0.1 \mathrm{ml}$ of serum sample and the mixture was incubated at $37^{\circ} \mathrm{C}$ for $30 \mathrm{~min}$. Then, $0.5 \mathrm{ml}$ of R2 containing $20 \mathrm{~min}$. Finally, $5 \mathrm{ml}$ of $\mathrm{NaOH}$ was added. The mixture was allowed to stand for $5 \mathrm{~min}$ at room temperature and the absorbance was read at $546 \mathrm{~nm}$. The activity of ALT in the homogenate was obtained from a standard curve.

\section{Evaluation of gamma-glutamyl transferase (GGT) activity}

The assay was conducted using a Randox kit manual. Using a water-bathe set at $37^{\circ} \mathrm{C}$ for the incubation of the reaction, the reaction is constituted of $100 \mu$ l of the sample extract $1000 \mu$ l of the reagent at a $\mathrm{pH}$ of 8.25 using tris-buffer of $100 \mathrm{mmol} / 1$ concentration. The reagent contains glycylglycine $(100 \mathrm{mmol} / \mathrm{l})$ and L- $\alpha$-glutamyl-3carboxy-4-nitroanilide $\quad(2.9 \mathrm{mmol} / \mathrm{l})$ The absorbance of the mixture was read at $405 \mathrm{~nm}$.

\section{Calculation}

To calculate the GGT activity the following formula was used:

$$
\mathrm{U} / \mathrm{L}=1158 \times \mathrm{A} 405 \mathrm{~nm} / \mathrm{min} .
$$

\section{Results and discussion}

The antioxidant activity of Momordica charantia extract scavenges DPPH radicals in concentration dependent manner (Fig. 2). This study shows that the extract has the proton donating ability and serves as free radical inhibitors or scavengers, acting as a primary antioxidant. The reducing power of the extract increased with increasing concentration (Fig. 3).

This is related to the ability of the antioxidant agent to transfer electron or $\mathrm{H}$ atom to oxidant or free radicals. Thus, antioxidant property of phenolics is due to their redox properties which allow them to act as hydrogen donors and singlet oxygen quenchers (Rice-Evans et al., 1996).

Generally, the chelating of iron is regarded as an antioxidant mechanism to prevent oxidative assault on biological macro molecules such as lipids, protein and nucleic acids. Free iron is a potential enhancer of 
reactive oxygen species formation, as it leads to reduction of $\mathrm{H}_{2} \mathrm{O}_{2}$ and generation of highly aggressive hydroxyl radicals that can perpetuate the chain reaction. This study revealed that $\mathrm{Hg}-$ administered group significantly reduced the concentration of kidney-sodium transport which suggest kidney malfunction. However, treatment with the extract help in bringing it back to near normal, these indicated the hepato-renal-protective attribute of Momordica charantia extract which could be traced to the natural compounds present in it. As presented in the figures below, the activities of ALT, AST, GGT and kidney-Sodium transport were significantly $(p<0.05)$ lowered in the groups exposed to mercury compared to values for control group (Figs. 4, 5, 6 and 7). Also, $\mathrm{Hg}-$ administered group significantly decreased activities of AST, ALT, and GGT.

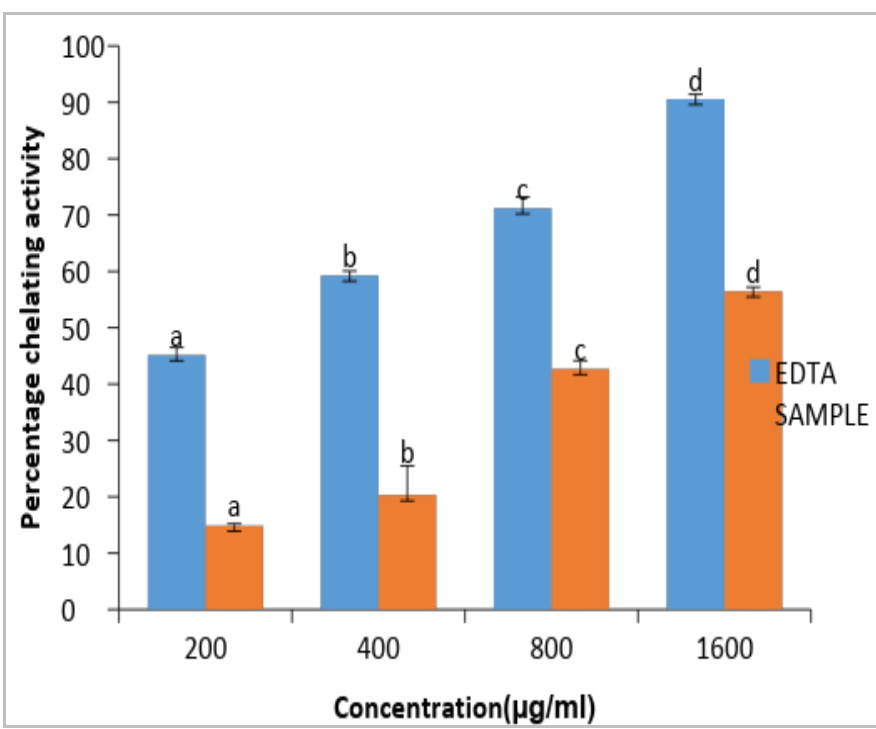

(A)

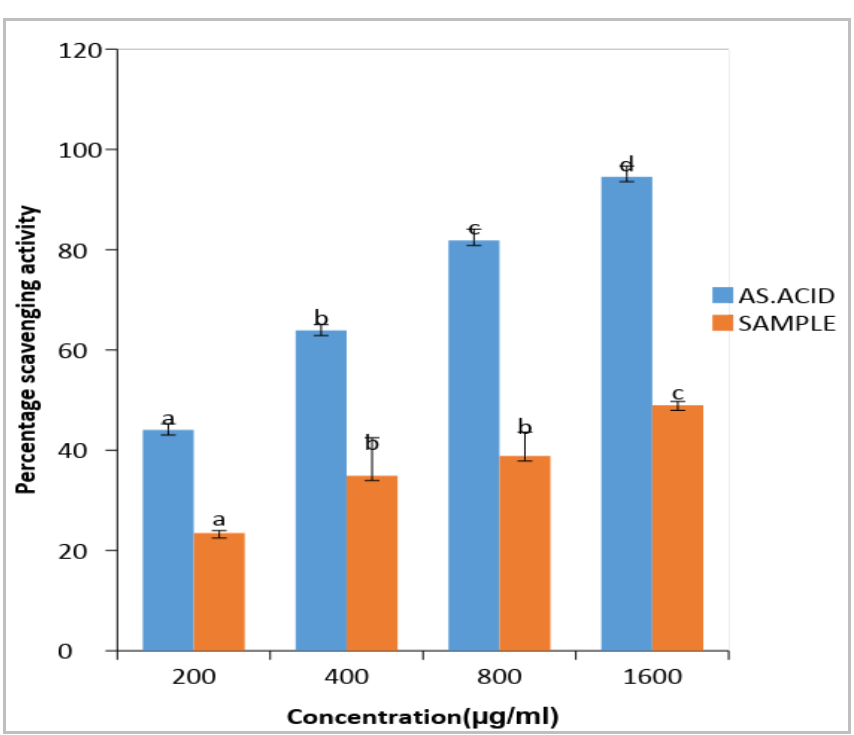

(B)

Fig. 2: (A) Metal chelating activity of Momordica charantia extract and (B) DPPH. Values with different superscript in a column are significantly different $(\mathrm{p}<0.05)$.

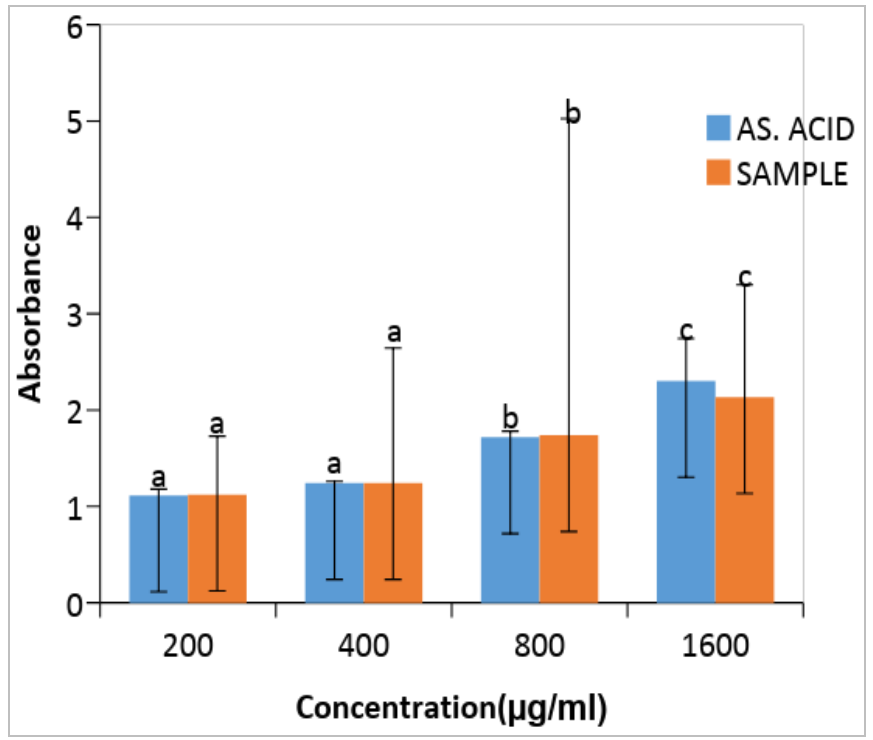

Fig. 3: Reducing power activity of Momordica charantia extract. Values with different superscript in a column are significantly different $(p<0.05)$.

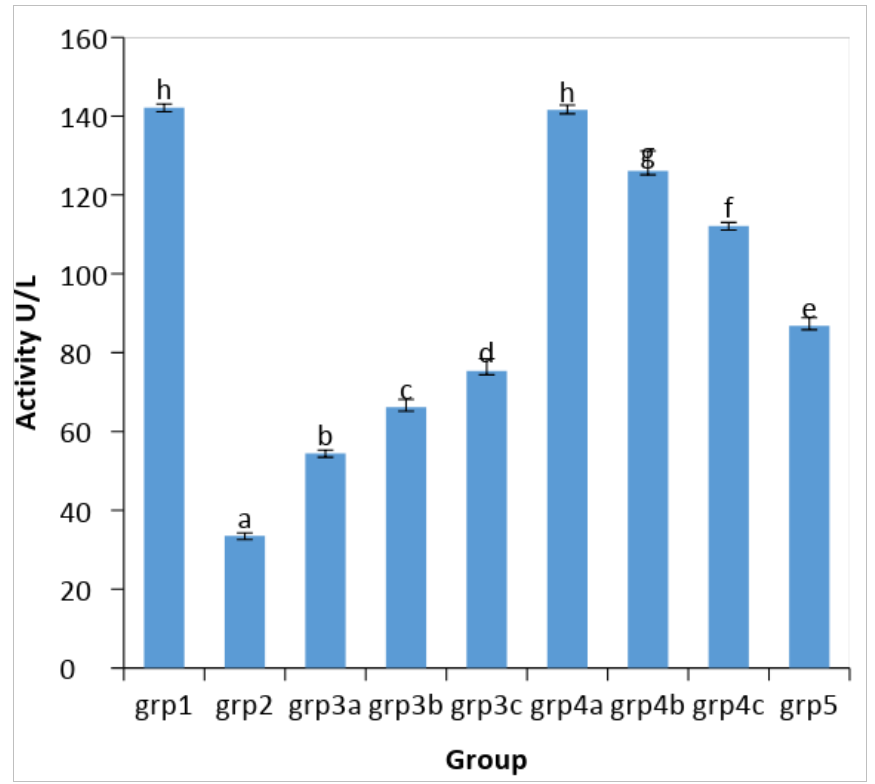

Fig. 4: Effect of Momordica charantia extract on liver ALT activity. 


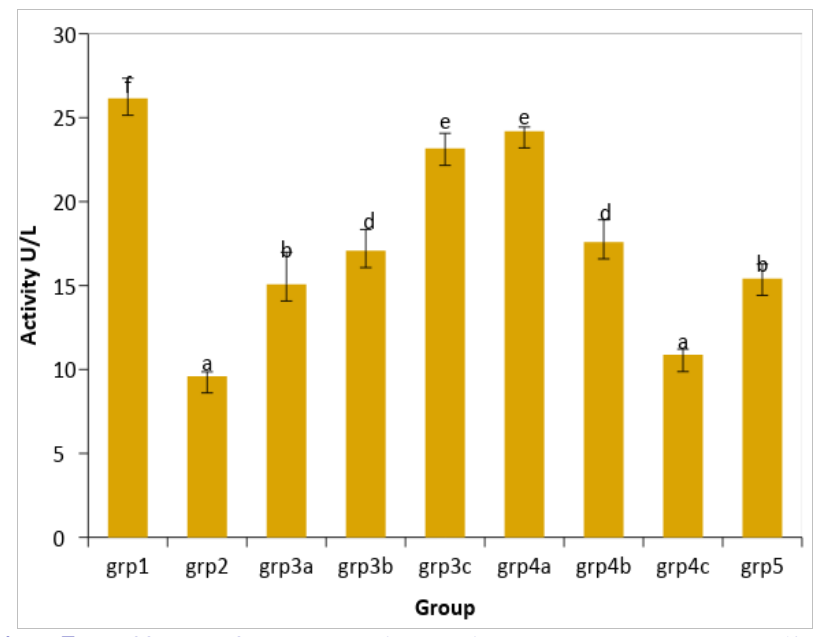

Fig. 5: Effect of Momordica charantia extract on liver AST activity.

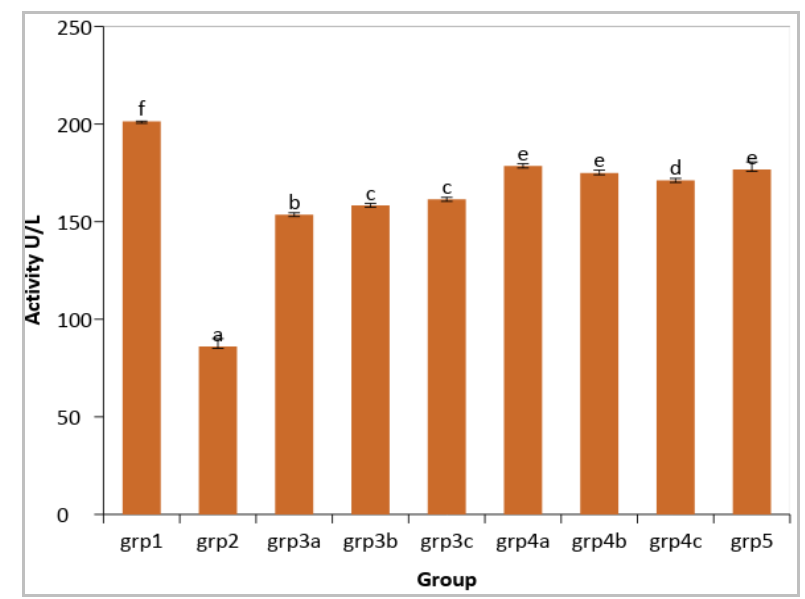

Fig. 6: Effect of Momordica charantia extract on liver GGT activity.

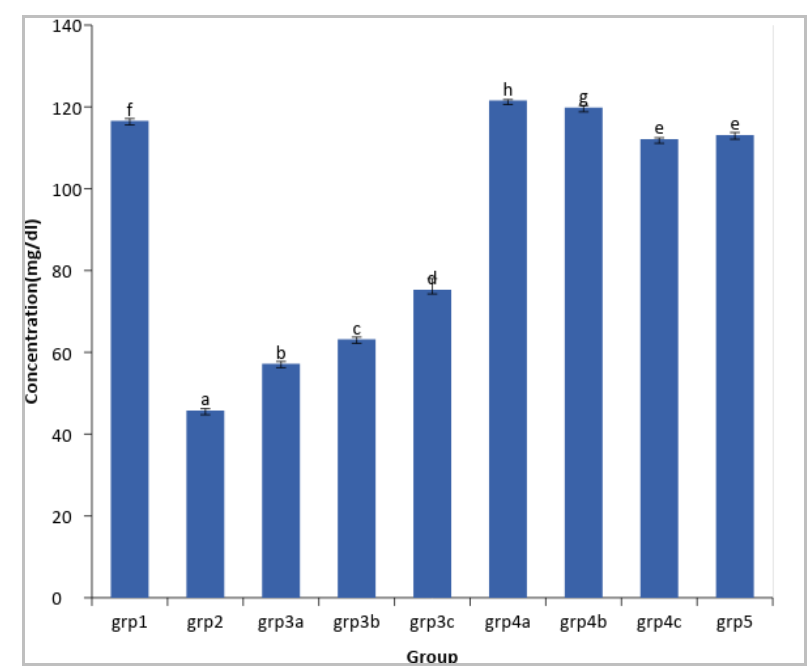

Fig. 7: Effect of Momordica charantia on kidney sodium concentration. Values with different superscript in a column are significantly different $(p<0.05)$.
Loss of activity of enzymes in the $\mathrm{Hg}$ administered group is a consequence of inactivation and degradation of enzyme and protein by $\mathrm{Hg}$ (Mercury), thus lowering enzyme activities. Present findings are in agreement with the findings of $\mathrm{El}-$ Demerdash (2001) who showed that $\mathrm{HgCl}$ intoxication significantly decreased ALT activity in rat. $\mathrm{Hg}$ is known to react with sulphydryl group, the cell membrane and impair their function, which is possible the cause of inhibition of AST and ALT activities. Treatment with Momordica charantia extract significantly increased the level of activities of ALT, AST, and GGT level in the liver homogenates of the treated groups. Chelating agents or chelators such as dimercapol and quercetin used in treatment of mercury poisoning generally competes with endogenous sulfhydryl, carboxyl, amine, amide and phosphate group. This could be possible mechanism of the modulatory action of the extract.

\section{Conflict of interest statement}

Authors declare that they have no conflict of interest.

\section{References}

Agrawal, M., Kamal, R., 2004. In vitro clonal propagation of Momordica charantia L. Ind. J. Biotech. 3, 426-430.

El-Demerdash, F., 2001. Effects of selenium and mercury on the enzymatic activities and lipid peroxidation in brain, liver, and blood of rats. J. Environ. Sci. Health B. 36, 489-499.

Grover, J. K., Yadav, S. P., 2004. Pharmacological actions and potential uses of Momordica charantia: A review. J. Ethnopharmacol. 93(1), 123-132.

Kumar, D.S., Sharathnath, K.V., Yogeswaran, P., Harani, A., Sudhakar, K., Sudha, P., Banji, D., 2010. A medicinal potency of Momordica charantia. Int. J. Pharmaceut. Sci. Rev. Res. 1(2), 95.

Lee-Huang, S., Huang, P. L., Chen, H. C., 1995. Anti-HIV and anti-tumor activities of recombinant MAP30 from bitter melon. Gene. 
161(2), 151-156.

Nadkarni, K.M., 2007. Indian Materia Medica. Vol.

1, Popular Prakashan Pvt. Ltd., Mumbai, India. pp.805-807.

Ng, T. B., Liu, W. K., Sze, S. F., Yeung, H. W., 1994. Action of $\alpha$-momorcharin, a ribosome inactivating protein, on cultured tumor cell lines. General Pharmacol. 25(1), 75-77.
Rice-Evans, C., Miller, N.J., Paganga, G., 1996. Structure-antioxidant activity relationships of flavonoids and phenolic acids. Free Rad. Biol. Med. 20, 933-956.

Shi, H., Hiramatsu, M., Komatsu, M., Kayama, T., 1996. Antioxidant property of Fructus momordicae extract. Biochem. Mol. Biol. Int. 40(6), 1111-1121.

\section{How to cite this article:}

Orji, E.E., Falodun, A.E., Jegede, F.I., 2018. The Antioxidant properties of Momordica charantia extract and its protective activities against in vitro mercury intoxication. Int. J. Curr. Res. Biosci. Plant Biol. 5(4), 30-35. doi: https://doi.org/10.20546/ijcrbp.2018.504.005 